\title{
DIGITAL CURRENCY STUDIES IN ISLAMIC PERSPECTIVE
}

\author{
Bedjo Santoso ${ }^{1}$, MA Irfan Rahmana ${ }^{2}$, Atin Anggraini Surono ${ }^{3}$
}

Fakultas Ekonomi dan Manajemen Universitas Islam Sultan Agung

Email: Bedjo.s@unissula.ac.id ${ }^{1}$, irfan.s@unissula.ac.id ${ }^{2}$, atinanggrainisurono@gmail.com ${ }^{3}$

\begin{abstract}
This study aims to determine the best type of Digital currency according to Islam. This study uses the Analytical Hierarchical Process (AHP) method by developing several alternative digital currencies and attributes (indicators).

In addition, this study also uses deductive qualitative analysis. Respondents in this study amounted to 100 people with the sampling technique Area Stratified Purposive Sampling and several selected respondents were interviewed.

The results show that Gold-based Digital Money is the best type of Digital currency according to Islam. The main attribute of ownership in Gold-based Digital Money is Usury abolishment capability. Other factors are Gharar Eraducation, Maysir Eraducation, Justice / Fairness Principles, Medium of exchange, Measurement of value, Store of value and Differed payment instrument. In addition, this model can accommodate 7 criteria for the role of currency in the economy.
\end{abstract}

Keywords: Digital currency, AHP, Deductive Analysis, Islamic Value.

\section{Introduction}

Digital money which is in its early stages in the form of Cryptocurrencies is rapidly proliferated around the world, especially since Bitcoin was launched in 2009. Initially it did not attract much attention even though the technology behind it was very innovative and advanced. Using cryptography and distributed ledger techniques, Bitcoin becomes the first global currency that is highly secure, unregulated and not issued by any central agency. In this case will be explained the three main types of digital currencies: Bitcoin, Altcoins, and Tokens. In addition, the Blockechain concept brings together three main types of digital currency. Bitcoin is the first blockchain. After Bitcoin, many new Blockechains were created called Altcoins. NEO, Litecoin, and Cardano are solid examples of Altcoins. Besides being known about Tokens/dApps, the main types of Cryptocurrencies include Civic (CVC), BitDegree (BDG), and WePower (WPR).

Many countries are very interested in developing digital currencies, such as Iran, Russia, India, Qatar and China. This is because they consider the fiat money faxed to USD is unfair and monopolistic which contradicts the concept of democracy in the use of currency. However, each country has not agreed on the implementation of the digital 
currency, there are even countries that refuse, including Indonesia. One thing they agree on is that they want to immediately end the hegemony of the USD over the domination of the world economy. Currently, not much study has been done in relation to digital money, let alone related to Islamic studies which are considered important considering that one of the important elements inherent in the value of money is that it is stable, fair and can function properly to serve the economy.

Study conducted by Meera (2018) highlights digital currency from the Maqashid Syariah aspect. Most sharia scholars are leaning towards approving Bitcoin as a digital currency based on the issue. Bitcoin is not fiat (paper) or real money. The absence of intrinsic value coupled with the lack or zero supervision by the central bank will result in the misuse of bitcoin. In addition, some scholars disagree because they have elements of Maysir, Usury and Gharar which are sources of socio-economic injustice, thus endangering Maqasid Al-Shari'ah. This study finally concludes that fiat cryptocurrencies are not shariacompliant. However, gold-backed cryptocurrencies are postulated to be desirable and consistent with Maqasid Al-shari'ah. This study uses subjective analysis as an expert researcher.

Another study was conducted by Ibrahim Bassam A. et.al. (2017) which uses a fiqh approach with a pure literature study which concludes that digital currency in this case is better than fiat money (paper money without intrinsic value). Study by Dodik S. et. Al (2020) entitled "The requirements of cryptocurrency for money, an Islamic view" which concludes that Cryptocurrency as digital money is more stable than fiat money and can be classified as a medium of digital currency exchange that has flexible characteristics of Cryptocurrency and its stability can intervention by the government. The method used is a quantitative method with time series fluctuation data for several digital currencies in several countries for five years.

Previous study in relation to digital currency from Islamic perspective is described in the following table:

\section{Table 1.}

Previous Study Digital currency from Islamic Perspective

\begin{tabular}{|c|l|l|l|}
\hline No & Author / Year & \multicolumn{1}{|c|}{ Result } & \multicolumn{1}{c|}{ Methods } \\
\hline 1 & Meera (2018) & $\begin{array}{l}\text { This study finally concludes that fiat } \\
\text { cryptocurrencies are not sharia compliant. } \\
\text { However, gold-backed cryptocurrencies are } \\
\text { postulated to be desirable and consistent } \\
\text { with Maqasid Al-shari'ah. This study uses } \\
\text { subjective analysis as an expert researcher. }\end{array}$ & Subjectic \\
\hline 2 & Ibrahim (2017) & $\begin{array}{l}\text { The results conclude that digital currency in } \\
\text { this case is better than fiat money (paper } \\
\text { money without intrinsic value). }\end{array}$ & $\begin{array}{l}\text { Figh Analysis and } \\
\text { Literature Study }\end{array}$ \\
\hline
\end{tabular}




\begin{tabular}{|c|c|l|l|}
\hline No & Author / Year & \multicolumn{1}{|c|}{ Result } & \multicolumn{1}{|c|}{ Methods } \\
\hline 3 & Dodik S (2020) & $\begin{array}{l}\text { Concluding that cryptocurrency as digital } \\
\text { money is more stable than fiat money and it } \\
\text { can be classified as a medium of digital } \\
\text { currency exchange that has flexible, and } \\
\text { stable characteristics. }\end{array}$ & $\begin{array}{l}\text { Quative, Simple } \\
\text { Statics. }\end{array}$ \\
\hline
\end{tabular}

From the existing study, it is necessary to develop a deductive analytical method to find the most suitable form of digital currency with Islamic values. Indicators of Islamic values and elements of the function of money need to be developed in this study.

\section{Review of Related Literature Definition of Digital / Cryptocurrency}

Cryptocurrency as an electronic money created with technology that controls its creation and protects transactions, while hiding the identity of its users. Blockchain is shared because it is run by many different people and companies, as opposed to a single company, such as a bank. In this way, no one person has more power in transactions or Cryptocurrencies.

The three main types of digital currencies Blockchain unites several types of digital currencies namely Bitcoin as the first form of Blockchain, Altcoin, NEO, Litecoin, and Cardano, Cryptocureency Token/dApps. Besides, it is known as Civic (CVC), BitDegree (BDG), and WePower (WPR).

Bitcoin is the most popular digital and Cryptocurrency developed by someone named Satoshi Nakamoto publishing online journals. However, it was later discovered that Satoshi Nakamoto was not the original name of the author. Even to this day, no one knows the real name of the originator of Bitcoin. In 2013-2014, Bitcoin grew rapidly then, experienced a slowdown. However, in 2017, the market for Bitcoin was steadily rising. In December 2017, Bitcoin reached a price of USD 20,000 per Bitcoin.

Altcoins are just an alternative version of Bitcoin with minor changes. It's important to understand that not all Altcoins are alternative versions of Bitcoin, there are some Bitcoins that are very different and serve very different purposes. Some Altcoins use different algorithms in Bitcoin. For example, Factim is an Altcoin that uses Proof of Stake (PoS). In PoS, there are no miners, only stakers.

Tokens (dApps) are the third type of Cryptocurrency. Of the three types of Cryptocurrencies, Tokens are the most attractive compared to the other two types. Tokens are very unique in that they do not have their own blockchain. This type is used in Apps (decentralized applications) which are applications that can be built on Blockchain such as Ethereum and NEO. DApps are built to use smart contracts, which is why they use tokens. Tokens don't have to represent a physical thing like electricity or a house but can be used 
to purchase items on the dApp or used to gain other benefits such as discount fees and voting fees.

\section{Islamic Money and Monetary Theory}

Long before the concept of money, barter trading systems existed where people traded the commodities they had for the commodities they needed. However, in a basic sense, it is easy to realize that such a concept has little effect on efficiency because it is not easy to match the gap between the commodity available and the commodity needed which is called the double coincidence of demand.

The concept of money was introduced to be a solution to the problems that exist in the barter trading system. Humans used several things ranging from shells, stones, metals like gold and silver and reaching to the current monetary system known as fiat money. Then, in modern society, paper money does not represent real value in its own design, not just a mere value unit of account to represent the value of commodities and their quantity is supplied and controlled by the central bank of each country where the bank controls it through monetary policy to achieve economic stability. Then use fiat money. Furthermore, the need for a medium of exchange with certain functions to facilitate trade is defined and performed certain functions which are mainly categorized in three main aspects: medium of exchange, unit of account and storage value.

The characteristics of money must have properties such assessment ability, durability, mobility, and share ability that make it easier to simplify transactions. Fiat money currently seems to bring about a controversial resolution among Islamic jurists. The first opinion goes towards the resolution that fiat money is not Sharia compliant as it creates purchasing power value from nothing and by increasing supply following inflation and the loss of currency value leading to other dangerous socio-economic problems such as poverty and wealth inequality. Furthermore, from a sharia perspective, the central bank issues currency following the government's objective to control and maintain its value, it is justified. Experts argue that although fiat money is inconvenient, it still serves the purpose of acting as money (Kamar et al, 2016). The Islamic fiqh academy of the Muslim world league issued a Sharia resolution on the nature and use of paper money. It was concluded that paper currency is an independent form of money and the rules that apply to gold and silver apply to it as well, in resolution 9D / 3 / 07 / 86, the OIC Fiqh Academy decided that paper currency is a legal tender that has the full quality of a medium of exchange and the rules that apply to gold and silver are applied to it.

An Islamic monetary expert, namely Meera \& Larbani (2009), seigniorage fiat money is considered only Usury and commodity money such as gold and silver in accordance with Sharia and in line with its objectives. In recent decades, new innovations from the development of digital currencies based on a supply and store of value foundation signaled for the better development of more stable currency options that are immune to the effects 
of inflation and market manipulation. Digital currencies especially those based on blockechain technology are proven to supply better mechanisms for money supply, inflation control and successfully achieve other socio-economic goals such as accessibility to finance and transparency.

Ibn Khaldun mentions the function of gold and silver also in his book "Muqaddimah" as money "Allah has created two metal stones Gold and Silver as a value for everyone to use in trade. Furthermore, AL Ghazali mentioned in his book Revival of Religious Science that "God is The almighty created them to change their hands, and to be judges between money and justice, and other wisdom, which asks them for other things, because they are dear to themselves, and have no purpose in themselves, and connect them with other things as one proportion".

Currency cannot be used as a commodity that is traded for price but as a medium of exchange only. Hence seeming controversial to modern Islamic scholars, classical scholars insist on using Gold and Silver as currency and treating them as pure and valueless mediums of exchange which eliminates the concept of earning interest on them under the justification of the time value of money.

\section{Sharia-compliant Digital Currency Development Debate}

Digital currency in the form of Blockechain and other digital currencies is becoming more familiar to individuals day by day, more literature is published with concepts that signify a comprehensive transformation in several aspects of life including political, social, and financial aspects with opportunities and countless solutions for the problems at hand.

The digital currency then helps to transform the financial system by giving it better tools to integrate more integrity, transparency and trust in it through the nature of Blockchain. The potential of digital currencies and blockchain looks huge. However, most of the literature that discusses its implementation is pursuing an easier way to claim that bitcoin and its payment system is Sharia compliant because it is a better alternative to fiat money and under the rules of necessity. This argument has some truth in it because fiat money in its core value does not have full compliance with the sharia.

Some opinions say that bitcoin and conventional digital currencies still have some problems in compliance with Sharia especially with digital currencies that do not have physical intrinsic value. Through Islamic history, Islam recognizes commodities with intrinsic physical value are only considered as money. The second problem is about its practicality in today's society where the government needs complete control over the monetary supply to control the economic conditions and keep it stable.

The sharia view of blockechain originality can be briefly discussed by examining whether it contains any elements of prohibition in Islam. From the previous discussion about blockechain, it is known that blockechain security includes public key cryptography and follows a decentralized network approach instead of a single server for recording and 
verifying transactions. The argument presented here is that in concept and content, the blockechain concept consists of computational and mathematical applications without any prohibited elements in its content.

The first problem with digital currencies is that they are completely decentralized where no one can control the supply or verification process. The government is currently proposing several ideas to include digital currencies such as blockechain in special regulations to promote their development. However, most governments are discouraged from promoting it and some even make trading it a legal activity.

According to Zahudi \& Amir (2016), "Virtual currencies are still largely uncharted and unattended areas, and so far, there is no possible protection available to consumers who engage virtual currencies if something goes wrong". Some literature may argue that the mining process (in blockechain) creates value for bitcoin and digital currencies and because there is effort in issuing currency, bitcoin has value for that currency. However, we still cannot find the physical existence of a currency that supports it and maintains its value in a real world which still causes problems in the definition of money from an Islamic perspective. One solution can be observed by attaching physical commodities to real-world digital currency reserves. In order to observe both the requirements of having an intrinsic value for the currency and solve the existing problems presented in the digital currency such as the volatility of its value over a short period of time, Gold can be observed as a commodity that deserves to be a reserve of the physical existence of the Digital currency. This step will solve two main problems in digital currencies, first is the volatility of digital currency prices because gold prices are much more stable.

One Gram from Dubai has issued the world's first gold-backed digital currency. It is like bitcoin in that it is created using blockchain technology and each coin is backed by one gram of gold. According to their website (One Gram), they collaborated with gold trading company "Gold Guard" and started an initial coin offering consisting of 12,400,786 coins. One of the standout features is Stability as it is associated with gold which sets the base for the coin price which is the same as the Gold price $(1 \mathrm{~g})$. The value of the currency grows as $70 \%$ of the transaction fee will be reinvested to buy more gold to increase the amount of gold backing each coin in which the owner will share the profits from it.

Al-Maqasid al-Shari'ah must be used as a measure so that Islamic law (Shari'ah) fulfills the 5 main higher goals to be protected and preserved. One of the goals is recognized as the Preservation of Wealth (Hifz al-Mal). There are several ways of preserving wealth in Islam. Wealth in Islam can be conserved through pursuing work and earning through permitted transactions and trading activities. Dangerous activities such as theft, ambiguity, gambling and interest are prohibited as they lead to the destruction of wealth. Therefore, engaging in any activity that destroys wealth is prohibited. Furthermore, adopting a currency that loses its value over time leads to the conclusion of the same wealth destruction 
and any currency that loses its value over time does not serve the function of money as a store of value.

Fiat money was created through a debt fractional reserve system and would not only oppose the objectives of sharia but lead to a move away from it (Meera \& Larbani, 2006). By examining the modified digital currency according to the case discussed, it will be considered to achieve the goal of preserving wealth because its creation is not based on debt or a fractional reserve system which will protect it from losing its value. However, over time, society finds that in order for an item to play the role of money effectively and efficiently it must meet certain requirements: Acceptable, Divisible, Homogeneous, Durable, Mobile, Rare and Stable.

\section{Study Methodology}

\section{Study Model Development}

From previous study, there is a gap that can be further developed to become a unique study, namely by using a qualitative deductive analysis method by conducting interviews with several experts to assess several alternative digital currency models with an assessment tool developed as follows:

Table 2.

Attribute Indicators and Digital Currency Alternatives

\begin{tabular}{|c|c|c|c|c|}
\hline \multirow[b]{2}{*}{ No } & \multirow[b]{2}{*}{ Indicator } & \multicolumn{3}{|c|}{ Alternative of Digital Currencies } \\
\hline & & $\begin{array}{c}\text { Fiat Money-based } \\
\text { Digital Money }\end{array}$ & $\begin{array}{c}\text { Real Assets-based } \\
\text { Digital Money }\end{array}$ & $\begin{array}{c}\text { Gold-based Digital } \\
\text { Money }\end{array}$ \\
\hline A & Islamic Value & & & \\
\hline 1 & $\begin{array}{l}\text { Usury abolishment } \\
\text { capability }\end{array}$ & contains Usury & $\begin{array}{c}\text { Able to Overcome } \\
\text { Usury }\end{array}$ & $\begin{array}{c}\text { Very Able to } \\
\text { Overcome Usury }\end{array}$ \\
\hline 2 & Gharar eradication & Contains Gharar & $\begin{array}{c}\text { Does Not Contain } \\
\text { Gharar }\end{array}$ & $\begin{array}{c}\text { Does Not Contain } \\
\text { Gharar }\end{array}$ \\
\hline 3 & Maysir eradication & $\begin{array}{c}\text { Contains } \\
\text { Gambling / } \\
\text { Speculation }\end{array}$ & $\begin{array}{c}\text { Does not contain } \\
\text { Gambling / } \\
\text { Speculation }\end{array}$ & $\begin{array}{c}\text { Does Not Contain } \\
\text { Gambling / } \\
\text { Speculation }\end{array}$ \\
\hline 4 & $\begin{array}{l}\text { Justice / Fairness } \\
\text { principles }\end{array}$ & $\begin{array}{l}\text { Unfair and } \\
\text { Destructive }\end{array}$ & Fair & Very Fair \\
\hline B & Function of Money & & & \\
\hline 1 & Medium of exchange & Could & Can & Can \\
\hline 2 & $\begin{array}{l}\text { Measurement of } \\
\text { value }\end{array}$ & Could & Can & Can \\
\hline 3 & Store of value & Not perfect & Can & Can \\
\hline 4 & $\begin{array}{l}\text { Differed payment } \\
\text { instrument }\end{array}$ & Could & Can & Can \\
\hline
\end{tabular}

The analysis is carried out by asking the opinions of experts and then concluded with a deductive analysis method so that the best digital currency model is obtained. In 
addition, assessment and analysis were also carried out by elaborating the following questions:

Table 3.

List of Questions regarding Digital Currency

\begin{tabular}{|c|c|}
\hline No & Questions regarding Digital Currency \\
\hline 1 & Is the chosen model capable of serving and mediating in modern economic exchanges? \\
\hline 2 & $\begin{array}{l}\text { Can the selected model be used as a medium for payment by account transaction (Account } \\
\text { Settlement)? }\end{array}$ \\
\hline 3 & Is the selected model able to store values well? \\
\hline 4 & $\begin{array}{l}\text { Is the selected model able to provide financing in capital formation to encourage economic } \\
\text { growth? }\end{array}$ \\
\hline 5 & Is the selected model a good measure of economic value? \\
\hline 6 & Is the selected model able to serve business needs well? \\
\hline 7 & Is the selected model in accordance with Islamic law? \\
\hline
\end{tabular}

\section{Study Objectives and Methodology}

The main objective of this study is to identify and examine specific aspects of digital currency from an Islamic perspective. Then try to identify and analyze alternative currency systems that are compared with the criteria that have been developed in the literature review chapter and the model.

Furthermore, by finding several alternatives that are integrated into an Islamic finance model that is compatible with the Islamic monetary system. Several analyzes were sought and developed both from theory, literature review and interview with interviewees, which are expected to determine the shortcomings of the current system in the fiat money system. Then it is expected to be able to answer whether digital currency can be a solution to solve the current currency system which is destructive, unfair and tends to crisis (Meera, 2018). The method used in this study is:

\section{Table 4.}

\section{Study Objectives and Methods}

\begin{tabular}{|c|c|c|c|}
\hline No. & Study Objectives & Method & Description \\
\hline 1 & $\begin{array}{l}\text { Find out the best type of } \\
\text { Digital currency } \\
\text { according to Islam }\end{array}$ & $\begin{array}{l}\text { AHP (Analytical } \\
\text { Hierarchical Process) }\end{array}$ & $\begin{array}{l}\text { Quantitative, involving } 100 \\
\text { respondents as shown in tables } 2 \\
\text { and } 3\end{array}$ \\
\hline 2 & $\begin{array}{l}\text { Studying digital currency } \\
\text { from an Islamic } \\
\text { perspective }\end{array}$ & $\begin{array}{lr}\text { Qualitative } & \text { literature } \\
\text { study with } & \text { a } \\
\text { combination } & \text { of } \\
\text { deductive } & \text { analysis } \\
\text { methods } & \text { (deductive } \\
\text { analysis) } & \end{array}$ & $\begin{array}{l}\text { Qualitative, deductive method } \\
\text { develops several alternative } \\
\text { currency models in accordance with } \\
\text { Islamic Value with several } \\
\text { attributes, by conducting interviews } \\
\text { with } 5 \text { experts consisting of } 2 \\
\text { scholars, } 2 \text { academics }\end{array}$ \\
\hline
\end{tabular}




\begin{tabular}{|l|l|l|}
\hline & & $\begin{array}{l}\text { Professor/Doctor) and 1 } \\
\text { practitioner of Islamic economics. }\end{array}$ \\
\hline
\end{tabular}

Qualitative study seeks to explore valid evidence and then present it in the form of a detailed analysis. Opinions and experiences as well as literature review support are expected to provide better conclusions, so as to be able to answer study objectives whose scope is in the field of monetary economics, especially the field of digital currency.

This study is a relatively new study because: First, digital currency including blockechain development is a new study topic especially after the development of the most famous digital currency in the world. Second, the study of Islamic perspectives on digital currencies is still an undeveloped area and not many researchers have done so that the development of models has not been widely obtained.

\section{Study Respondents}

Respondents of this study amounted to 100 people with a sampling technique Area Stratified Purposive Sampling, which is detailed as follows:

Table 5

Distribution of Respondents Area

\begin{tabular}{|l|c|c|c|}
\hline \multirow{2}{*}{ Area } & \multicolumn{3}{|c|}{ Number of Respondent } \\
\cline { 2 - 4 } & Ulama & Academics & $\begin{array}{c}\text { Islamic Economic } \\
\text { Activists }\end{array}$ \\
\hline Area 1 & 20 & 10 & 10 \\
\hline Area 2 & 10 & 3 & 2 \\
\hline Area 3 & 5 & 5 & 5 \\
\hline Area 4 & 5 & 8 & 6 \\
\hline Area 5 & 4 & 5 & 2 \\
\hline
\end{tabular}

The hundred respondents above, were taken from the Java Island Region. Area 1 consists of major cities in Java (Jakarta, Surabaya, Bandung, and Semarang), Area 2 (Bogor, Yogyakarta, Malang), Area 3 (Purwokerto, Surakarta, Tegal, Jember and Ponorogo), Area 4 (Banten, Kudus, Pati), Area 5 (Tuban, Jombang, Kediri, Berbes, Cirebon and Majalengka). After that, 5 people were selected to be interviewed with the following details:

Table 6

Respondents interviewed

\begin{tabular}{|c|l|c|c|c|}
\hline No & \multicolumn{1}{|c|}{ Institution } & Education & Qualification & Code \\
\hline A & \multicolumn{3}{|c|}{ Ulama } \\
\hline 1 & Indonesian Council of Ulama & Ph.D & ULAMA & UL1 \\
\hline 2 & $\begin{array}{l}\text { Chairman of the Islamic Da'wah } \\
\text { Council }\end{array}$ & Ph.D & $\begin{array}{l}\text { 8 years as } \\
\text { Chairman }\end{array}$ & UL2 \\
\hline B & \multicolumn{4}{|c|}{ Academics } \\
\hline
\end{tabular}




\begin{tabular}{|c|l|c|c|c|}
\hline No & \multicolumn{1}{|c|}{ Institution } & Education & Qualification & Code \\
\hline 1 & $\begin{array}{l}\text { Lecturer of Islamic Economics and } \\
\text { Finance (ICMI) }\end{array}$ & Professor & 18 years & AK1 \\
\hline 2 & Lecturer of Islamic Economics & Ph.D & 11 years & AK2 \\
\hline C & \multicolumn{2}{|c|}{ Islamic Economic Activists } \\
\hline 1 & ICMI and CHAIRMAN ISEFID & Ph.D & 12 years & EI1 \\
\hline
\end{tabular}

\section{Analytical Hierarchical Process (AHP)}

The Analytical Hierarchy Process (AHP) is a multi-criteria decision-making approach and was introduced by Saaty (Pezzullo L \& Filippo RD, 2009). AHP regulates basic rationality by breaking down problems into smaller parts. By outlining the problem, the decision maker can focus on a number of items at the same time.

AHP is carried out in two stages: hierarchical design and evaluation of components in the hierarchy (Stock RJ \& Lambert DM, 2013). AHP is especially suitable for complex decisions that involve comparisons of decision elements that are difficult to measure. It is based on the assumption that when faced with a complex decision, the natural human reaction is to group the decision elements according to their general characteristics and it is a decision-making technique in which there are a finite number of choices, but where each has a number of different attributes, some or all of them may be difficult to formalize (Saaty TL, 2004 and Tung SL \& Tang SL, 1998). This is especially true when a team is making decisions. It involves building a hierarchy (Rank) of decision elements and then making comparisons between each possible pair in each cluster (as a matrix). It assigns a weight to each element in the cluster (or hierarchical level) and a consistency ratio (useful for checking data consistency) (Uma Devi K, Elango C, Rajesh R, 2012).

The steps involved in the AHP process are given below: first, In the AHP method, the following steps are carried out (Saaty, 2006) Define the problem and determine the desired solution. Second, Create a hierarchical structure that begins with the main goal. Third, Create a pairwise comparison matrix that describes the relative contribution or influence of each element on the objectives or criteria at the level above it. Fourth, Perform pairwise comparisons so that the total number of assessments is $\mathrm{n} \times[(\mathrm{n}-1) / 2]$ pieces, where $\mathrm{n}$ is the number of elements being compared. And the last, Conducting an assessment using the pairwise comparison scale and its meaning introduced by Saaty can be seen below.

Intensity of Interest:

$1=$ Both elements are equally important, Two elements have the same effect.

$3=$ One element is slightly more important than the other, Experience and judgment slightly favor one element over the other.

$5=$ One element is more important than the other, Experience and judgment strongly favor one element over the other. 
$7=$ One element is clearly more absolutely important than the other elements, One element that is strongly supported and dominant is seen in practice.

$9=$ One element is absolutely important than the other elements, Evidence supporting one element against another has the highest possible level of affirmation.

$2,4,6,8=$ Values between two values of adjacent considerations, This value is given when there are two compromises between 2 choices. On the contrary, if for activity i gets one point compared to activity $j$, then $j$ has the opposite value compared to $i$.

First, Calculate the eigenvalues and test the consistency, if it is not consistent then the data collection is repeated. Second, repeat steps 3,4 and 5 for all levels of the hierarchy and the last calculate the eigenvector of each pairwise comparison matrix which is the weight of each element for determining the priority of the elements at the lowest hierarchical level to achieve the goal. The calculation is conducted by adding up the values of each column of the matrix, dividing each value from the column by the corresponding column total to obtain a normalized matrix, and adding up the values from each row and dividing by the number of elements to get the average.

And the last check the consistency of the hierarchy. What is measured in the AHP is the consistency ratio by looking at the consistency index. The expected consistency is near perfect in order to produce a decision that is close to valid. Although it is difficult to achieve perfect, the expected consistency ratio is less than or equal to $10 \%$.

\section{Results and Discussion}

\section{Determining the Digital Money Model}

In this study used 3 Alternatives and 8 Factors/Attributes as follows: Alternative: Digital Money Based on Flat Money, Real Asset Based Digital Money and Gold-Based Digital Money.

\section{Attributes/Factors}

\section{Islamic Values}

The relationship between Alternative and attribute/factor indicators is described as follows: 1) Usury Abolishment Capability. 2) Gharar Eradication, 3) Maysir Eradication. 4) Justice / Fairness Principles.

Function of Money is for Medium of Exchange, Measurement of Value, Store of Value, Differentiated Payment Instruments. 


\section{Figure 1}

\section{Relationship between Attributes and Alternatives}

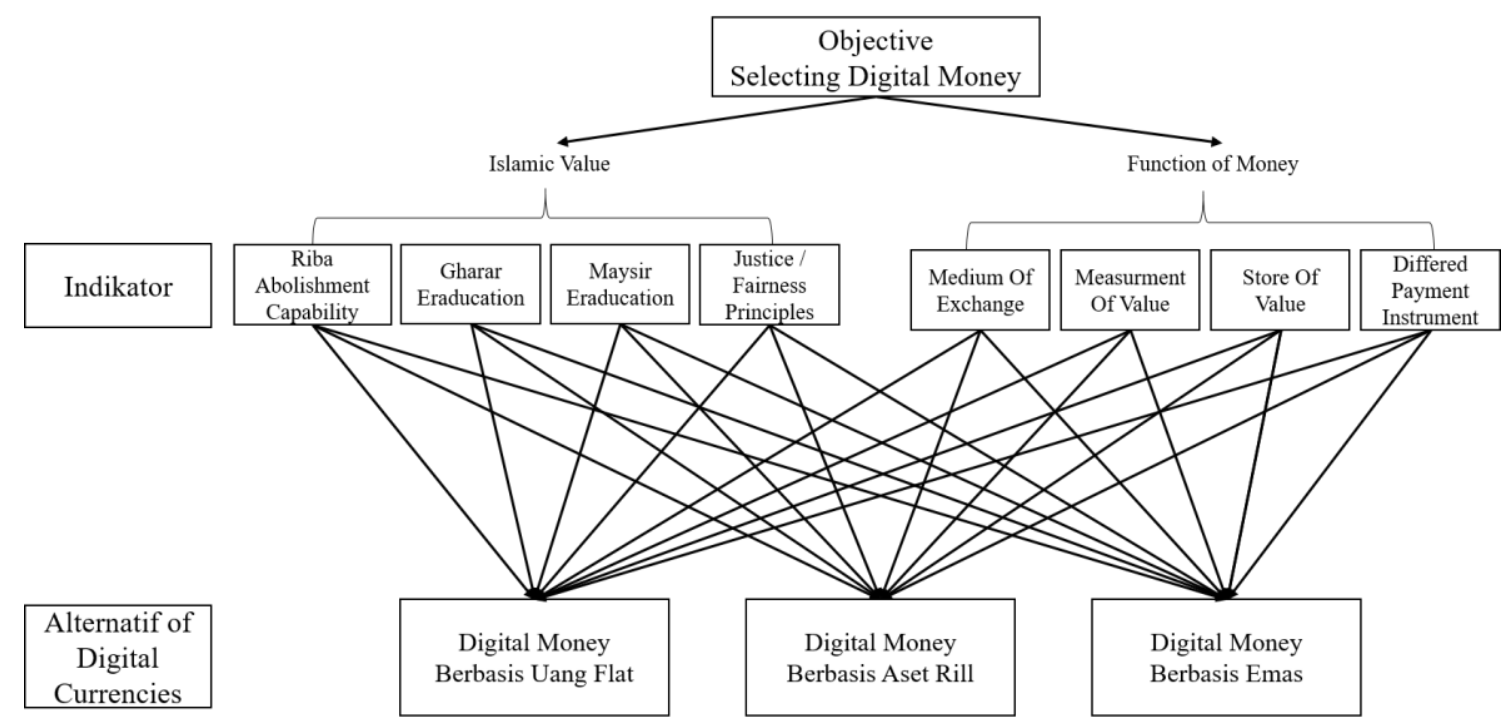

The next step is the calculation with the Comparison Matrix :

Table 7

Matrix of Respondents Paired Assessment Results regarding Attributes

\begin{tabular}{|c|c|c|c|c|c|c|c|c|c|}
\hline Attributes & I1 & I2 & I3 & I4 & I5 & I6 & I7 & I8 & Weights \\
\hline I1 & 1 & $1 / 2$ & 1 & 1 & $1 / 2$ & 1 & $1 / 2$ & 1 & 0.081 \\
\hline I2 & 2 & 1 & 2 & 2 & 1 & 2 & 1 & $1 / 2$ & 0.157 \\
\hline I3 & 1 & $1 / 2$ & 1 & 1 & 1 & $1 / 2$ & 1 & 1 & 0.098 \\
\hline I4 & 1 & $1 / 2$ & 1 & 1 & 2 & 1 & $1 / 2$ & 2 & 0.130 \\
\hline I5 & 2 & 1 & 1 & $1 / 2$ & 1 & 2 & 2 & 1 & 0.145 \\
\hline I6 & 1 & $1 / 2$ & 2 & 1 & $1 / 2$ & 1 & 1 & 2 & 0.123 \\
\hline I7 & 2 & 1 & 1 & 2 & $1 / 2$ & 1 & 1 & $1 / 2$ & 0.123 \\
\hline I8 & 1 & 2 & 1 & $1 / 2$ & 1 & $1 / 2$ & 2 & 1 & 0.132 \\
\hline
\end{tabular}

Table 8

Alternative Paired Matrix Normalization Calculation Results

\begin{tabular}{|c|c|c|c|c|}
\hline I1 & Alt $\mathbf{1}$ & Alt $\mathbf{2}$ & Alt 3 & Weights \\
\hline Alt 1 & 1 & 2 & 1 & 0.236 \\
\hline Alt 2 & $1 / 2$ & 1 & $1 / 2$ & 0.1796 \\
\hline Alt 3 & 1 & 2 & 1 & 0.2367 \\
\hline
\end{tabular}


Table 9

Final Evaluation Results of Attribute Relationships with Alternatives

\begin{tabular}{|c|c|c|c|c|c|c|c|c|c|c|c|}
\hline \multirow{3}{*}{ Altern } & \multirow{3}{*}{ Weight } & \multicolumn{8}{|c|}{ Attributes and their weights } & \multirow{3}{*}{$\begin{array}{l}\text { Composite } \\
\text { weights }\end{array}$} & \multirow{3}{*}{ Rank } \\
\hline & & I1 & $\mathrm{I} 2$ & I3 & I4 & I5 & I6 & I7 & I8 & & \\
\hline & & 0,5625 & 1,0924 & 0,6826 & 0,9028 & 1,0097 & 0,8569 & 0,8583 & 0,9167 & & \\
\hline 1 & 1,644 & 0.2367 & 0.2448 & 0.3373 & 0.1556 & 0.1981 & 0.3404 & 0.1768 & 0.2377 & 1,6479 & 3 \\
\hline 2 & 1,247 & 0.1796 & 0.2536 & 0.1260 & 0.6588 & 0.5709 & 0.2791 & 0.4335 & 0.2919 & 1,7083 & 2 \\
\hline 3 & 2,998 & 0.2367 & 0.1671 & 0.2631 & 0.0859 & 0.1025 & 0.1920 & 0.1947 & 0.2697 & 2,009 & 1 \\
\hline
\end{tabular}

Based on the calculations in table 9, the results of the final evaluation of the relationship between alternatives and attributes with the first rank are alternative three, it is gold-based Digital Money with a total Composite Weights of 2,009. The second rank is alternative two, it is Digital Money based on real assets with a total Composite Weights of 1,708. Ultimately, alternative one is Digital Money based on fiat money with a composite weight of 1,647 . So it can be concluded that alternative 3 which is gold-based Digital Money is the best type of Digital currency according to Islam.

\section{Table 10}

\section{Attribute Assessment Per Alternative}

\begin{tabular}{|l|l|}
\hline \multicolumn{2}{|c|}{ ALTERNATIVE 1 } \\
\hline I6 & 0.3404 \\
\hline I3 & 0.3373 \\
\hline I2 & 0.2448 \\
\hline I8 & 0.2377 \\
\hline I1 & 0.2367 \\
\hline I5 & 0.1981 \\
\hline I7 & 0.1768 \\
\hline I4 & 0.1556 \\
\hline
\end{tabular}

\begin{tabular}{|l|l|}
\hline \multicolumn{2}{|c|}{ ALTERNATIVE 2} \\
\hline I4 & 0.6599 \\
\hline I5 & 0.5709 \\
\hline I7 & 0.4335 \\
\hline I8 & 0.2919 \\
\hline I6 & 0.2791 \\
\hline I2 & 0.2536 \\
\hline I1 & 0.1796 \\
\hline I3 & 0.1260 \\
\hline
\end{tabular}

\begin{tabular}{|c|c|}
\hline \multicolumn{2}{|c|}{ ALTERNATIVE 3 } \\
\hline I1 & 0.2998 \\
\hline I8 & 0.2697 \\
\hline I3 & 0.2631 \\
\hline I7 & 0.1947 \\
\hline I6 & 0.1920 \\
\hline I2 & 0.1671 \\
\hline I5 & 0.1025 \\
\hline I4 & 0.0859 \\
\hline
\end{tabular}

Furthermore, table 10 shows the Attribute Measurement per Alternative. In the first alternative (fiat money based Digital Money), attribute 6 is Measurement of value has the biggest value that is 0.3404 . The second position is attribute 3 or Maysir eradication with the value as 0.3373 . And the third is attribute 2 or Gharar eradication with the value as 0.2448. In the second alternative (real asset based Digital Money), the value the biggest value is attribute 4 or Justice/ Fairness principles with the value as 0.6588 , the second biggest value is attribute 5 of Medium of exchange with the value as 0.5709 , and the third 
is attribute 7 or Store of value with the value as 0.4335 . The last, in the third alternative (gold based Digital Money), the unit attribute or Riba abolishment capability has the biggest value that is 0.2998 , then attribute 8 or Differed Payment Instrument has the second biggest value as 0.2697 and the third is attribute 3 of Maysir eradication with the value as 0.2631.

The most important factor affecting the fiat money based Digital Money or (alternative 1) is Measurement of value (attribute 6). Then, the most important factor affecting the real asset based Digital Money (alternative 2) is Justice/ Fairness principles (attribute 4). And the most important factor affecting the gold based Digital Money (alternative 3) is Riba abolishment capability (attribute 1).

From the interview results conducted to 5 selected respondents and combined with the deductive analysis produces the conclusion as in table 10 below:

Table 11

\begin{tabular}{|c|c|c|c|c|}
\hline \multicolumn{5}{|c|}{ Respondents' Interview Results } \\
\hline \multirow[b]{2}{*}{ No } & \multirow[b]{2}{*}{ Indicator } & \multicolumn{3}{|c|}{ Alternative of Digital Currencies } \\
\hline & & $\begin{array}{l}\text { Fiat Money based } \\
\text { Digital Money }\end{array}$ & $\begin{array}{c}\text { Real Asset based } \\
\text { Digital Money }\end{array}$ & $\begin{array}{c}\text { Gold based Digital } \\
\text { Money }\end{array}$ \\
\hline A & Islamic Value & & & \\
\hline 1 & $\begin{array}{l}\text { Riba abolishment } \\
\text { capability }\end{array}$ & Contains riba & $\begin{array}{l}\text { Capable to overcome } \\
\text { riba }\end{array}$ & $\begin{array}{l}\text { Very capable to } \\
\text { overcome riba }\end{array}$ \\
\hline 2 & Gharar eradication & Contains Gharar & Not contain Gharar & Not contain Gharar \\
\hline 3 & Maysir eradication & $\begin{array}{l}\text { Contains Gambling/ } \\
\text { Speculation }\end{array}$ & $\begin{array}{ll}\text { Not } & \text { contain } \\
\text { Gambling/ } & \\
\text { Speculation } & \end{array}$ & $\begin{array}{ll}\text { Not } & \text { contain } \\
\text { Gambling/ } & \\
\text { Speculation } & \end{array}$ \\
\hline 4 & $\begin{array}{l}\text { Justice/ Fairness } \\
\text { principles }\end{array}$ & Unfair and damage & Fair & Very Fair \\
\hline & $\begin{array}{l}\text { Function of } \\
\text { Money }\end{array}$ & & & \\
\hline 1 & $\begin{array}{l}\text { Medium of } \\
\text { exchange }\end{array}$ & May & Able & Able \\
\hline 2 & $\begin{array}{l}\text { Measurement of } \\
\text { value }\end{array}$ & May & Able & Able \\
\hline 3 & Store of value & Not perfect & Able & Able \\
\hline 4 & $\begin{array}{l}\text { Differed payment } \\
\text { instrument }\end{array}$ & May & Able & Able \\
\hline
\end{tabular}

The analysis is done by asking the opinion of the experts and concluded with deductive analysis method so that it is obtained the best digital currency model. The best Digital Currency in Islam's perspective according to the general respondents' view is Gold based Digital Currency because it is very capable to overcome riba, not contain Gharar, not contain gambling/ speculation and very Fair. Other than that, it can function as Medium of exchange, measurement of value, Store of value and Differed payment instrument. 
Furthermore, also conducted measurement and analysis by elaborating the questions below:

Table 12

\section{List of Questions about Digital Currency}

\begin{tabular}{|l|l|}
\hline \multicolumn{1}{|c|}{ No } & \multicolumn{1}{|c|}{ Questions about Digital Currency: } \\
\hline 1 & Is the selected model capable of serving and mediating in modern economic exchanges? \\
\hline 2 & $\begin{array}{l}\text { Can the selected model be used as a media for payment by account transaction (Account } \\
\text { Settlement)? }\end{array}$ \\
\hline 3 & \begin{tabular}{l} 
Is the selected model able to store values well? \\
Is the selected model able to provide financing in capital formation to encourage the economic \\
\hline 4
\end{tabular} \\
\hline 6 & Is the selected model a good measure of economic value? \\
\hline 7 & Is the selected model able to serve business needs well? \\
\hline
\end{tabular}

\section{The Respondents' Opinion Through the In-Depth Interview}

Based on the table 13 below, it is showed the opinion of the respondents to the first, second and third alternative from the seven indicator aspects reflecting the currency system whether they can work well or not.

Table 13.a

Respondents' Measurement of Alternative 3

\begin{tabular}{|c|c|c|c|c|c|c|}
\hline \multicolumn{7}{|c|}{ ALTERNATIVE 3} \\
\hline & & \multicolumn{5}{|c|}{$\begin{array}{l}\text { RESPONDENTS' MEASUREMENT } \\
\text { (INTERVIEW) }\end{array}$} \\
\hline No & Question about Digital Currency: & UL1 & UL2 & AK1 & AK2 & ES1 \\
\hline 1 & $\begin{array}{l}\text { Is the selected model capable of serving and } \\
\text { mediating in modern economic exchanges? }\end{array}$ & Yes & Yes & Yes & Yes & Yes \\
\hline 2 & $\begin{array}{l}\text { Can the selected model be used as a media for } \\
\text { payment by account transaction (Account } \\
\text { Settlement)? }\end{array}$ & Yes & Yes & Yes & Yes & Yes \\
\hline 3 & Is the selected model able to store values well? & Yes & Yes & Yes & Yes & Yes \\
\hline 4 & $\begin{array}{l}\text { Is the selected model able to provide financing } \\
\text { in capital formation to encourage the economic } \\
\text { growth? }\end{array}$ & Yes & Yes & Yes & Yes & Yes \\
\hline 5 & $\begin{array}{l}\text { Is the selected model a good measure of } \\
\text { economic value? }\end{array}$ & Yes & Yes & Yes & Yes & Yes \\
\hline 6 & $\begin{array}{l}\text { Is the selected model able to serve business } \\
\text { needs well? }\end{array}$ & Yes & Yes & Yes & Yes & Yes \\
\hline 7 & $\begin{array}{l}\text { Is the selected model in accordance with Islamic } \\
\text { law? }\end{array}$ & Yes & Yes & Yes & Yes & Yes \\
\hline
\end{tabular}


Table 13.b.

Respondents' Measurement of Alternative 2

\begin{tabular}{|c|c|c|c|c|c|c|}
\hline \multicolumn{7}{|c|}{ ALTERNATIVE 2} \\
\hline & & \multicolumn{5}{|c|}{$\begin{array}{c}\text { RESPONDENTS' MEASUREMENT } \\
\text { (INTERVIEW) }\end{array}$} \\
\hline No & Question about Digital Currency: & UL1 & UL2 & AK1 & AK2 & ES1 \\
\hline 1 & $\begin{array}{l}\text { Is the selected model capable of serving and } \\
\text { mediating in modern economic exchanges? }\end{array}$ & Yes & Yes & Yes & Yes & Yes \\
\hline 2 & $\begin{array}{l}\text { Can the selected model be used as a media for } \\
\text { payment by account transaction (Account } \\
\text { Settlement)? }\end{array}$ & Yes & Yes & Yes & Yes & Yes \\
\hline 3 & Is the selected model able to store values well? & Yes & Yes & Yes & Yes & Yes \\
\hline 4 & $\begin{array}{l}\text { Is the selected model able to provide financing } \\
\text { in capital formation to encourage the economic } \\
\text { growth? }\end{array}$ & Yes & Yes & Yes & Yes & Yes \\
\hline 5 & $\begin{array}{l}\text { Is the selected model a good measure of } \\
\text { economic value? }\end{array}$ & Yes & Yes & Yes & Yes & Yes \\
\hline 6 & $\begin{array}{l}\text { Is the selected model able to serve business } \\
\text { needs well? }\end{array}$ & Yes & Yes & Yes & Yes & Yes \\
\hline 7 & $\begin{array}{l}\text { Is the selected model in accordance with Islamic } \\
\text { law? }\end{array}$ & No & No & Yes & No & Yes \\
\hline
\end{tabular}

Table 13.c.

Respondents' Measurement of Alternative 1

\begin{tabular}{|c|c|c|c|c|c|c|}
\hline \multicolumn{7}{|c|}{ ALTERNATIVE 1} \\
\hline & & \multicolumn{5}{|c|}{$\begin{array}{c}\text { RESPONDENTS' MEASUREMENT } \\
\text { (INTERVIEW) }\end{array}$} \\
\hline No & Question about Digital Currency: & UL1 & UL2 & AK1 & AK2 & ES1 \\
\hline 1 & $\begin{array}{l}\text { Is the selected model capable of serving and } \\
\text { mediating in modern economic exchanges? }\end{array}$ & Yes & Yes & Yes & Yes & Yes \\
\hline 2 & $\begin{array}{l}\text { Can the selected model be used as a media for } \\
\text { payment by account transaction (Account } \\
\text { Settlement)? }\end{array}$ & Yes & Yes & Yes & Yes & Yes \\
\hline 3 & Is the selected model able to store values well? & Yes & Yes & Yes & Yes & Yes \\
\hline 4 & $\begin{array}{l}\text { Is the selected model able to provide financing } \\
\text { in capital formation to encourage the economic } \\
\text { growth? }\end{array}$ & Yes & Yes & Yes & Yes & Yes \\
\hline 5 & $\begin{array}{l}\text { Is the selected model a good measure of } \\
\text { economic value? }\end{array}$ & Yes & Yes & Yes & Yes & Yes \\
\hline 6 & $\begin{array}{l}\text { Is the selected model able to serve business } \\
\text { needs well? }\end{array}$ & Yes & Yes & Yes & Yes & Yes \\
\hline 7 & $\begin{array}{l}\text { Is the selected model in accordance with Islamic } \\
\text { law? }\end{array}$ & No & No & No & No & No \\
\hline
\end{tabular}


From the table above, it can be explained that a gold based digital currency system can meet seven indicators. This means that a gold based digital currency can guarantee well that the currency system can function properly. While in other systems there are still weaknesses. Some respondents (three out of five respondents) think that real asset based digital money is not in accordance with Islamic law. And the five respondents above agreed that fiat money based digital money is not in accordance with Islamic law.

To support the argument above the following shows the summary manuscript of the interview to the 5 respondents above, as follows: UL1 stated that gold based Digital Money is the currency system that can meet the money function criteria and meet the Islamic value. Because this system (gold based) does not contain riba, gharar, maisyir (speculation) and support the creation of maqosyid syariah in realizing the justice. It is different with the fiat money based Digital Money that still contains speculation element.

UL2 stated that gold based digital money can function as media of Medium of Exchange, Measurement of Value, Store of Value and Differed Payment Instrument with good function. The weakness of gold is the mobility, because gold cannot be carried anywhere easily. But it can be overcome by the gold only as value measurement and the value is kept in the form of digital that can be stored in the mobile phone so that each transaction both payment and withdrawal can be done by using mobile phone.

AK1 stated that Fiat Money based digital money still contains Riba because the nominal value is not the same as the intrinsic value (nominal and intrinsic value). Other than that, the fiat money allows the occurrence of FRB (Fractional Reserve Banking/ Reuairement). With the FRB concept bank can print the money more than the real asset, and then will encourage the price increase and inflation. While the gold-based system does not contain riba, gharar, maisyir (speculation) and able to create the justice in the society.

AK2 stated that fiat money based Digital Money still allows the instability of currency value (the value decreases from time to time). It is different with the gold value which is stable from time to time even according to the Royjustrame's research in his book Golden Constant if the gold is determined as value measurement, then from 300 years ago the prices would be stable. While Real Asset based Digital Money, has quite good capability as long as the commodity prices are stable (crude oil and other mining materials).

ES1 stated that Fiat Money based Digital Money, can accelerate the economic growth because fiat money can be printed easily, but has bubble value weakness so that the amount of money is more than the real asset (until 2015, the amount of distributed money was 900 times more than the real asset). In the end, it will encourage the global financial crisis. It is different with the gold, even though the amount is limited, but can be used as media to encourage the economic growth with the gold function as measurement of value 
and backed up by digital/ ICT. For Real Asset based Digital Money has capability which is not as good as Gold based Digital Money.

\section{Conclusion}

Based on the research that has been conducted and discussed above, then can be concluded as follows: 1) Gold based Digital Money is the best Digital currency type according to Islam. 2) The most important factor in affecting the Fiat Money based Digital Money or (alternative 1) is Measurement of value (attribute 6). Then, the most important factor in affecting the Real Asset based Digital Money (alternative 2) is Justice/ Fairness principles (attribute 4). And the most important factor affecting the Gold based Digital Money (alternative 3) is Riba abolishment capability (attribute 1).

The last, the best digital currency in Islam perspective according to the general respondents' view is Gold based Digital Currency because very capable to overcome Riba, not contain Gharar, not contain Gambling/ Speculation and very Fair. Other than that, can function as Medium of exchange, Measurement of value, Store of value and Differed Payment Instrument. Furthermore, able to serve and mediate in modern economics exchange, can be used as media in payment by account transaction (Account Settlement), can store the value well, able to provide the funding in the form of capital to encourage the economic growth, as a good economic value measurement, able to serve the business requirements and has been in accordance with the Islamic law.

\section{Bibliography}

Abdullah, A. (2013). The Gibson paradox: Real gold, interest rates and prices.International Business Research,6(4), 32.https://doi.org/10.5539/ibr.v6n4p32

Abdullah, A. (2016). The Islamic currency. Kuala Lumpur: International Council of Islamic Finance Educators.

Dodik, S. et.al, 2020, The requirements of cryptocurrency for money, an Islamic view, journal homepage: www.cell.com/heliyon, 2020.

Ibrahim Bassam A. et.al, 2007, Developing a Digital currencyfrom an Islamic Perspective: Case of Blockchain Technology: IIUM Institute of Islamic Banking and Finance, Malaysia. Received:August 24, 2017Accepted:September 7, 2017Online Published: September29, 2017, doi:10.5539/ibr.v10n11p79URL: https://doi.org/10.5539/ibr.v10n11p79

Meera, (2018) Cryptocurrencies From Islamic Perspectives: The Case Of Bitcoin, Bulletin of Monetary Economics and Banking, Volume 20, Number 4, April 2018.

Pezzullo L, Filippo RD (2009) Perceptions of industrial risk and emergency management procedures in Hazmat Logistics: A qualitative mental model approach. Safety Science 47:537-541.

Stock RJ, Lambert DM (2013) Strategic logistics management. International Journal of Physical Distribution \& LogisticsManagement. 
Saaty TL (2004) Decision making - the Analytic Hierarchy and Network Processes (AHP/ANP). Journal of Systems Science and Systems Engineering 13:1-35.

Tung SL, Tang SL (1998) A comparison of the Saaty's AHP and modifiedAHP for right and left eigenvector inconsistency. European Journal of Operational Research 106:123128.

Uma Devi K, Elango C, Rajesh R (2012) Vendor selection using AHP. In Procedia Engineering 38:1946-1949. 